\title{
Analisis Kebutuhan Petugas Rekam Medis Berdasarkan Beban Kerja di Instalasi Rekam Medis RS Aisyiah Muntilan
}

\author{
Fitria Rakhmawati ${ }^{1}$, Ery Rustiyanto ${ }^{2}$ \\ Program Studi DIII Rekam Medis SV UGM ${ }^{1}$, Rumah Sakit Akademik UGM ${ }^{2}$ \\ Fitriarakhmawati.fr@gmail.com , ery_rustiyanto@ugm.ac.id
}

\begin{abstract}
ABSTRAK
Latar Belakang: Berdasarkan hasil observasi, RS Aisyiah Muntilan memiliki 7 orang petugas rekam medis yang terdiri dari 4 orang petugas pendaftaran dan 3 orang petugas pengolahan data dan pelaporan. Petugas pendaftaran terbagi dalam 3 shift yaitu: pagi, siang, malam, dan hari libur. Dengan adanya poliklinik saat shift pagi, petugas pendaftaran yang hanya 1 orang merasa keteteran dalam melayani pasien. Untuk membantu petugas pendaftaran, biasanya petugas pengolahan data dan pelaporan diturunkan sehingga akan mempengaruhi beban kerja petugas pengolahan data dan pelaporan. Oleh karena itu, peneliti ingin mengetahui bagaimana beban kerja dan kebutuhan petugas rekam medis di RS Aisyiah Muntilan untuk mengetahui kebutuhan petugas secara keseluruhan dengan menggunakan metode WISN (Workload Indicator Staff Need) berdasarkan analisis problem solving yang dilakukan.
\end{abstract}

Tujuan: Mengidentifikasi jumlah petugas rekam medis yang tersedia, mengidentifikasi uraian tugas petugas rekam medis, mengidentifikasi hambatan yang ada di Instalasi Rekam Medis dan solusinya, menghitung standar waktu kegiatan di Instalasi Rekam Medis, menghitung kebutuhan tenaga berdasarkan beban kerja di Instalasi Rekam Medis

Metode: Jenis penelitian adalah deskriptif dengan pendekatan kuantitatif dan rancangan penelitian crossectional. Sampel penelitian adalah petugas rekam medis di RS Aisyiah Muntilan dengan sampel terbatas.

Hasil: Setelah dilakukan perhitungan kebutuhan petugas dengan rumus WISN ternyata tidak diperlukan penambahan petugas. Hal ini menunjukan bahwa beban kerja yang tinggi bukan karena kurangnya petugas namun karena sistem yang ada di pendaftaran dan poliklinik yang kurang baik.

Kesimpulan: Penambahan petugas tidak diperlukan namun perlu perbaikan sistem yang ada.

Kata Kunci : Rekam medis, Analisis, Kebutuhan Petugas, Petugas Rekam Medis, Beban Kerja.

\begin{abstract}
Background: Based on the observation RS Aisyiah Muntilan has 7 medical records officers consisting of four admissions officers and three officers enrollment data processing and reporting. The admissions officers divided into 3 shift work 1 officers for morning-noon, 1 officers for lunchafternoon, 1 officers for night-early morning, and 1 officers absent. With the clinic when the morning shift, the admissions officers that only one person felt that lag in serving patients. To assist the registration process is usually another officer assigned to help so it will affect the workload of reporting and data processing officers. Therefore, researchers wanted to know how the workload and the needs of the medical record officers in RS Aisyiah Muntilan to determine the overall needs of officers using WISN (Workload Indicator Staff Need) based on the analysis of problem solving.

Objective: To identify the number of medical records officers available, identify the descriptions of tasks medical record officers, identifying barriers and solutions, calculate the standard time activities at the installation of medical records and calculate power requirements based on the workload at the installation of medical records.
\end{abstract}

Methods: The study was descriptive qualitative approach and phenomenological research design. The subject of research is medical record officers in RS Aisyiah Muntilan. The object of research is the workload of medical record officers .

Results: After calculation formula needs WISN officer was not required additional personnel. This shows that the high workload is not due to lack of personnel, but because the existing system of registration and clinical activities that are less good.

Conclusion: Extra officers are not required but need improvement of existing systems .

Keywords: Medical Record, Analysis, Officers Needs, The Medical Record Officer, Workload 


\section{PENDAHULUAN}

Berdasarkan hasil observasi, RS Aisyiah Muntilan memiliki 7 orang petugas rekam medis yang terdiri dari 4 orang petugas pendaftaran dan 3 orang petugas pelaporan dan pengolahan data. Petugas pendaftaran terbagi dalam 3 shift yaitu: pagi 1 orang petugas, siang 1 orang petugas, malam 1 orang petugas dan 1 orang petugas libur. Dengan adanya poliklinik saat shift pagi, petugas pendaftaran yang hanya 1 orang merasa keteteran dalam melayani pasien. Selain itu, pasien juga harus mengantri lama sampai tempat duduk yang disediakan oleh rumah sakit kurang, tidak jarang banyak pasien yang berdiri menunggu. Untuk membantu petugas pendaftaran, biasanya petugas pengolahan data dan pelaporan diturunkan sehingga akan mempengaruhi beban kerja petugas pengolahan data dan pelaporan. Oleh karena itu, peneliti ingin mengetahui bagaimana beban kerja dan kebutuhan petugas rekam medis di RS Aisyiah Muntilan untuk mengetahui kebutuhan petugas secara keseluruhan dengan menggunakan metode WISN (Workload Indicator Staff Need) berdasarkan analisis problem solving yang dilakukan. Tujuan dari penelitian ini adalah untuk mengetahui jumlah kebutuhan tenaga rekam medis berdasarkan beban kerja di RS Aisyiah Muntilan

\section{METODE}

Jenis penelitian yang digunakan dalam penelitian ini adalah deskriptif dengan pendekatan kualitatif. Sedangkan rancangan penelitian yang digunakan dalam penelitian ini adalah fenomenologi.

Subjek yang digunakan dalam penelitian ini adalah petugas rekam medis di RS Aisyiah Muntilan. Objek. Sedangkan objek penelitian dalam penelitian ini adalah beban kerja petugas rekam medis. Instrumen yang digunakan antara lain: Checklist observasi; pedoman wawancara; checklist studi dokumentasi; buku catatan dan alat tulis; alat perekam dan stopwatch. Teknik Pengumpulan data yang dilakukan antara lain dengan wawancara, observasi dan studi dokumentasi. Data yang didapatkan dianalisis dengan tahapan data reduction, data display dan Conclusion drawing/verification.

\section{HASIL DAN PEMBAHASAN}

\section{A. Hasil}

1. Jumlah petugas yang tersedia Berdasarkan hasil wawancara dan observasi, jumlah petugas rekam medis yang tersedia di RS Aisyiah Muntilan adalah 7 orang petugas.

2. Uraian tugas di Instalasi Rekam Medis

Berdasarkan hasil studi dokumentasi uraian tugas tertulis, yang berlaku adalah sebagai berikut:

a. Penerimaan Pasien Baru

1) Mengkoordinir penerimaan pasien baru yang mencakup kegiatan wawancara, pengawasan pengisian formulir pendaftaran pasien baru dan input data sosial pasien.

2) Menyiapka berkas Rekam Medis baru yang terdiri dari:

a. Kartu berobat pasien

b. Penomoran rekam medis

3) Mendistribusikan berkas Rekam Medis pasien baru ke IGD dan klinik yang dituju.

b. Penerimaan Pasien Lama

1) Melaksanakan penerimaan pasien lama.

2) Mempersilahkan pasien untuk menuju klinik yang dituju.

3) Memesan berkas Rekam Medis ke bagian filling.

4) Mengentry ke dalam komputer semua pasien yang akan berobat.

5) Mendistribusikan berkas Rekam Medis ke masingmasing klinik dan IGD.

6) Menyediakan alat dan peralatan yang diperlukan.

c. Pelaksana pengambilan dan penyimpanan berkas Rekam Medis

1) Untuk keperluan berobat, petugas mendapat pesanan berkas rekam medis dari tempat pendaftaran dan 
ditulis pada tracer warna kuning.

2) Pesanan diambil dengan mencocokan nomor rekam medis dan nama pasien, jika sudah cocok tinggalkan tracer sebagai pengganti berkas rekam medis yang keluar.

3) Berkas untuk keperluan berobat kemudian diluncurkan ke ruang penerimaan pasien untuk didistribusikan, sedangkan berkas untuk asuransi diberikan kepada petugas yang memesan sesuai dengan ketentuan yang ada.

4) Berkas yang telah selesai digunakan, kemudian dimasukkan kembali ke almari penyimpanan yang sesuai.

5) Untuk menghindari kesalahan pengembalian, sesuaikan dengan tracer yang ada, tracer dikeluarkan dan digunakan lagi untuk keperluan selanjutnya

d. Analisis dan Assembling

1) Menganalisis kelengkapan pengisian berkas rekam medis secara kuantitatif dengan variabel analisis: identifikasi, autentikasi dan catatan yang penting.

2) Membuat laporan bulanan sebagai bahan bagi rapat panitia rekam medis tentang tingkat kecenderungan ketidaklengkapan pengisian berkas rekam medis.

3) Menyusun ulang berkas rekam medis yang telah kembali dari rawat inap sesuai dengan urutan form rekam medis yang telah ditetapkan.

e. Koding dan Indexing

1) Membuat laporan bulanan sebagai bahan bagi rapat panitia rekam medis tentang tingkat kecenderungan ketidaklengkapan pengisian.
2) Mengkode diagnosa pasien rawat jalan kedalam ICD X.

3) Laporan 10 besar penyakit rawat jalan, jumlah pasien berdasarkan dokter dan kelompok penyakit, jumlah pasien perhari buka klinik dan jumlah kematian IGD.

4) Mengkode diagnosa pasien rawat inap kedalam ICD X.

5) Laporan 10 besar penyakit rawat inap, jumlah pasien berdasarkan dokter dan kelompok penyakit, jumlah pasien perhari buka klinik dan jumlah kematian IGD.

f. Pelaporan

1) Membuat rekapitulasi pasien rawat jalan dan rawat inap.

2) Membuat indicator mutu pelayanan.

3. Hambatan dan Solusi

Berdasarkan hasil observasi dan wawancara diketahui bahwa terdapat beberapa hambatan yang berasal dari faktor man, method, dan prasarana yaitu sebagai berikut:

a. Keterbatasan jumlah sumber daya manusia terutama saat shift pagi.

b. Petugas merasa kewalahan dalam melayani pasien.

c. Pasien terkadang membawa persyaratan yang kurang lengkap.

d. Pasien dating secara bersamaan di pagi hari.

e. Pasien melakukan kritik/ complain.

f. SOP yang ada masih belum mencakup semua prosedur pelayanan yang ada di pendaftaran.

g. Uraian tugas tertulis masih ada yang belum sesuai dengan tugas di lapangan.

h. Kurangnya ruang tunggu dan tempat duduk untuk pasien yang mendaftar.

Berdasarkan hasil wawancara, Instalasi Rekam Medis telah melakukan beberapa cara untuk 
mengatasi hambatan yang ada yaitu sebagai berikut:

a. Instalasi Rekam Medis telah mengajukan penambahan petugas namun belum ada tindakan lebih lanjut dari rumah sakit.

b. Pemberian sistem nomor antrian di pendaftaran.

4. Standar Waktu Kegiatan

Berikut adalah hasil perhitungan standar waktu kegiatan di Instalasi Rekam Medis:

Tabel 1. Standar Waktu Kegiatan

\begin{tabular}{|c|c|c|}
\hline No & Kegiatan & $\begin{array}{l}\text { Waktu } \\
\text { (menit) }\end{array}$ \\
\hline 1 & $\begin{array}{l}\text { Pendaftara pasien baru } \\
\text { poliklinik dan IGD (umum) }\end{array}$ & 4,12 \\
\hline 2 & $\begin{array}{l}\text { Pendaftaran pasien lama } \\
\text { poliklinik dan IGD(umum) }\end{array}$ & 1,15 \\
\hline 3 & $\begin{array}{l}\text { Pendaftaran pasien baru } \\
\text { poliklinik dan IGD (BPJS) }\end{array}$ & 6,47 \\
\hline 4 & $\begin{array}{l}\text { Pendaftaran pasien lama } \\
\text { poliklinik dan IGD (BPJS) }\end{array}$ & 3,76 \\
\hline 5 & $\begin{array}{l}\text { Pendaftaran pasien rawat } \\
\text { inap (umum) }\end{array}$ & 7,9 \\
\hline 6 & $\begin{array}{l}\text { Pendaftaran pasien rawat } \\
\text { inap (BPJS) }\end{array}$ & 9,4 \\
\hline 7 & $\begin{array}{l}\text { Menyediakan status rawat } \\
\text { inap }\end{array}$ & 1,08 \\
\hline 8 & $\begin{array}{l}\text { Memasukkan backup data } \\
\text { pasien baru ke computer }\end{array}$ & 0,58 \\
\hline 9 & $\begin{array}{l}\text { Mengambil berkas rekam } \\
\text { medis }\end{array}$ & 1,97 \\
\hline 10 & $\begin{array}{l}\text { Mendistribusikas berkas } \\
\text { rekam medis ke poli }\end{array}$ & 1,18 \\
\hline 11 & $\begin{array}{l}\text { Mendistribusikan berkas } \\
\text { rekam medis ke IGD }\end{array}$ & 2,1 \\
\hline 12 & $\begin{array}{l}\text { Mendistribusikan berkas } \\
\text { rekam medis ke lab dan } \\
\text { radiologi }\end{array}$ & 0,62 \\
\hline
\end{tabular}

Tabel 1. (lanjutan) Standar Waktu Kegiatan

\begin{tabular}{clcc}
\hline No & \multicolumn{1}{c}{ Kegiatan } & $\begin{array}{c}\text { Waktu } \\
\text { (menit) }\end{array}$ \\
\hline 13 & $\begin{array}{l}\text { Mendistribusikan berkas } \\
\text { rekam medis ke fisiotherapi }\end{array}$ & 4,06 \\
\hline 14 & $\begin{array}{l}\text { Mendistribusikan berkas } \\
\text { rekam medis ranap }\end{array}$ & 2,08 \\
\hline 15 & $\begin{array}{l}\text { Mengembalikan berkas ke } \\
\text { rak filling }\end{array}$ & 1,85 \\
\hline 16 & $\begin{array}{l}\text { Menggabungkan } \\
\text { menyimpan berkas }\end{array}$ & dan & 2,63 \\
\hline 17 & Assembling & 4,94 \\
\hline 18 & Coding rawat jalan & 1,98 \\
\hline 19 & Coding rawat inap & 2,30 \\
\hline 20 & Indexing rawat jalan & 1,08 \\
\hline 21 & Indexing rawat inap & 1,31 \\
\hline 24 & $\begin{array}{l}\text { Peb. Lap indicator } \\
\text { pelayanan }\end{array}$ & 149,59 \\
\hline 25 & Membuat SKM & 33,35 \\
\hline 26 & Klaim BPJS ralan & 4,1 \\
\hline 27 & Klaim BPJS ranap & 5,22 \\
\hline & &
\end{tabular}

5. Menghitung kebutuhan petugas rekam medis

a. Menetapkan waktu kerja tersedia

1) Pendaftaran IGD, laboratorium dan rawat inap $8760 \mathrm{jam} / \mathrm{tahun}$

2) Pendaftaran poliklinik dan fishioteraphi $\quad 1820$ $\mathrm{jam} / \mathrm{tahun}$

3) Pendaftaran laboratorium dan radiologi 3078 $\mathrm{jam} / \mathrm{tahun}$

4) Pengolahan data dan pelaporan $1820 \mathrm{jam} / \mathrm{tahun}$

b. Menetapkan unit kerja dan kategori SDM

Unit kerja yang dihitung kebutuhan tenaga kerjanya adalah petugas rekam medis.

c. Menyusun standar beban kerja

Standar Beban Kerja $=\frac{\text { Waktu kerja tersedia }}{\text { Rata }- \text { rata waktu kegiatan pokok }}$

Tabel 2 Standar Beban Kerja Pendaftaran

\begin{tabular}{clc}
\hline No & \multicolumn{1}{c}{ Kegiatan Pokok } & SBK \\
\hline 1 & $\begin{array}{l}\text { Pendaftaran pasien baru } \\
\text { (Umum) }\end{array}$ & 26492 \\
\hline
\end{tabular}


Tabel 2. (lanjutan) Standar Beban Kerja Pendaftaran

\begin{tabular}{llc}
\hline No & Kegiatan Pokok & SBK \\
\hline 2 & $\begin{array}{l}\text { Pendaftaran pasien lama } \\
\text { (Umum) }\end{array}$ & 95288 \\
\hline 3 & $\begin{array}{l}\text { Pendaftaran pasien baru } \\
\text { (BPJS) }\end{array}$ & 16883 \\
\hline 4 & $\begin{array}{l}\text { Pendaftaran pasien lama } \\
\text { (BPJS) }\end{array}$ & 29027 \\
\hline 5 & $\begin{array}{l}\text { Pengambilan } \\
\text { medis }\end{array}$ & 55487 \\
\hline 6 & Distribusi berkas rekam ke poliklinik & 92385 \\
\hline 7 & $\begin{array}{l}\text { Distribusi berkas ke fisiotherapi } \\
26883\end{array}$ \\
\hline 8 & $\begin{array}{l}\text { Pengembalian berkas rekam } \\
\text { medis }\end{array}$ & 59091 \\
\hline
\end{tabular}

Tabel 3. Standar Beban Kerja di Pendaftaran IGD, rawat inap dan Laboratorium

\begin{tabular}{|c|c|c|}
\hline $\mathrm{No}$ & Kegiatan Pokok & SBK \\
\hline 1 & $\begin{array}{l}\text { Pendaftaran pasien baru } \\
\text { IGD atau laboratorium } \\
\text { (Umum) }\end{array}$ & 127510 \\
\hline 2 & $\begin{array}{l}\text { Pendaftaran pasien lama } \\
\text { IGD atau laboratorium } \\
\text { (Umum) }\end{array}$ & 458638 \\
\hline 3 & $\begin{array}{l}\text { Pendaftaran pasien baru } \\
\text { IGD (BPJS) }\end{array}$ & 81261 \\
\hline 4 & $\begin{array}{l}\text { Pendaftaran pasien lama } \\
\text { IGD (BPJS) }\end{array}$ & 139713 \\
\hline 5 & $\begin{array}{l}\text { Pendaftaran pasien rawat } \\
\text { inap (Umum) }\end{array}$ & 66514 \\
\hline 6 & $\begin{array}{l}\text { Pendaftaran pasien rawat } \\
\text { inap (BPJS) }\end{array}$ & 55903 \\
\hline 7 & $\begin{array}{ll}\text { Pengambilan } & \text { berkas } \\
\text { rekam medis } & \end{array}$ & 267073 \\
\hline 8 & Distribusi berkas ke & 250285 \\
\hline 9 & Distribusi status rawat & 252449 \\
\hline 10 & $\begin{array}{l}\text { Distribusi berkas ke } \\
\text { laboratorium }\end{array}$ & 850485 \\
\hline 11 & $\begin{array}{l}\text { Pengembalian berkas } \\
\text { rekam medis }\end{array}$ & 284415 \\
\hline 12 & $\begin{array}{l}\text { Penyimpanan dan } \\
\text { penggabungan status } \\
\text { rawat inap dengan } \\
\text { berkas rawat jalan }\end{array}$ & 200000 \\
\hline 13 & $\begin{array}{l}\text { Pembuatan status rawat } \\
\text { inap }\end{array}$ & 486666 \\
\hline 14 & $\begin{array}{l}\text { Input backup data } \\
\text { pasien baru }\end{array}$ & 903092 \\
\hline
\end{tabular}

Tabel 4 Standar Beban Kerja di Pendaftaran Radiologi

\begin{tabular}{cll}
\hline No & Kegiatan Pokok & SBK \\
\hline 1 & Pendaftaran pasien & 161151 \\
\hline
\end{tabular}

Tabel 4. (lanjutan) Standar Beban Kerja di Pendaftaran Radiologi

\begin{tabular}{lll}
\hline No & Kegiatan Pokok & SBK \\
\hline 2 & $\begin{array}{l}\text { Pengambilan berkas } \\
\text { rekam medis (Umum) }\end{array}$ & 93841 \\
\hline 3 & $\begin{array}{l}\text { Distribusi berkas } \\
\text { ke radiologi (BPJS) }\end{array}$ & 298834 \\
\hline 4 & $\begin{array}{l}\text { Pengembalian } \\
\text { berkas rekam medis }\end{array}$ & 99935 \\
\hline
\end{tabular}

Tabel 5. Standar Beban Kerja Pengolahan Data dan Pelaporan

\begin{tabular}{|c|c|c|}
\hline No & Kegiatan Pokok & SBK \\
\hline 1 & Assembling & 22195 \\
\hline \multirow[t]{3}{*}{2} & Coding & \\
\hline & a.Coding rawat jalan & 55151 \\
\hline & b.Coding rawat inap & 47519 \\
\hline \multirow[t]{3}{*}{3} & Indexing & \\
\hline & a.Indexing rawat jalan & 101111 \\
\hline & b.Indexing rawat inap & 83486 \\
\hline \multirow[t]{4}{*}{4} & Laporan bulanan & \\
\hline & $\begin{array}{l}\text { a. Laporan } 10 \text { besar } \\
\text { penyakit rawat jalan }\end{array}$ & 4287 \\
\hline & $\begin{array}{l}\text { b. Laporan } 10 \text { besar } \\
\text { penyakit rawat inap }\end{array}$ & 5399 \\
\hline & $\begin{array}{l}\text { c. Laporan bulanan } \\
\text { indikator mutu } \\
\text { pelayanan }\end{array}$ & 730 \\
\hline 5 & $\begin{array}{l}\text { Pembuatan surat } \\
\text { keterangan medis }\end{array}$ & 3274 \\
\hline \multirow[t]{3}{*}{6} & Klaim BPJS & \\
\hline & $\begin{array}{ll}\text { a. } & \begin{array}{l}\text { Klaim BPJS rawat } \\
\text { jalan }\end{array} \\
\end{array}$ & 26647 \\
\hline & $\begin{array}{l}\text { b. Klaim BPJS rawat } \\
\text { inap }\end{array}$ & 20919 \\
\hline
\end{tabular}

d. Menyusun standar kelonggaran Faktor kelonggarannya adalah rapat 2 jam/ bulan di shift pagi Faktor kelonggarannya adalah 0,0132 .

e. Perhitungan SDM

Berdasarkan data pelaporan kunjungan pasien tahun 2015 dinyatakan bahwa jumlah kunjungan pasien baru poliklinik umum 4515 orang dan lama 17122 orang. Pasien baru poliklinik BPJS 1113 orang dan lama 3486 orang. Pasien baru IGD umum 4953 orang dan lama 6221 orang. Pasien baru 
IGD BPJS 492 orang dan lama 795 orang. Pasien rawat inap umum 3166 orang dan BPJS 1797 orang. Pasien radiologi 2172 orang, pasien fisiotherapi 1502 orang, pasien laboratorium baru 521 orang dan lama 3367 orang.

Berikut adalah hasil perhitungan kebutuhan petugas di tiap kegiatan:

Tabel 6. Kebutuhan SDM rekam medis

\begin{tabular}{clc}
\hline No & \multicolumn{1}{c}{ Kegiatan } & $\begin{array}{c}\text { Kebutuhan } \\
\text { SDM } \\
\text { (orang) }\end{array}$ \\
\hline 1 & $\begin{array}{l}\text { Pendaftaran } \\
\text { poliklinik dan } \\
\text { fisiotherapi }\end{array}$ & 1,77 \\
\hline 2 & $\begin{array}{l}\text { Pendaftaran rawat } \\
\text { inap, IGD dan } \\
\text { laboratorium }\end{array}$ & 0,4 \\
\hline 3 & Pendaftaran radiologi & 0,07 \\
\hline 4 & $\begin{array}{l}\text { Pengolahan data dan } \\
\text { pelaporan }\end{array}$ & 2,1 \\
\hline
\end{tabular}

\section{B. Pembahasan}

1. Petugas rekam medis yang tersedia Menurut Menpan RI (2013), formasi jabatan fungsional perekam medis untuk rumah sakit tipe D adalah tenaga terampil 15 orang dan tenaga ahli 4 orang petugas.

Jumlah petugas rekam medis yang tersedia di RSIA Aisyiah Muntilan adalah 7 orang petugas rekam medis dengan rincian 4 orang petugas pendaftaran dan 3 orang petugas pelaporan dan pengolahan data. Berdasarkan dari peraturan diatas jumlah petugas rekam medis masih belum sesuai dengan jumlah petugas rekam medis berdasarkan ketentuan yang ada.

2. Uraian tugas di Instalasi Rekam Medis

Menurut Hasibuan (2005), uraian pekerjaan adalah informasi yang bersifat tertulis yang menguraikan tugas dan tanggung jawab, kondisi pekerjaan, hubungan pekerjaan, dan aspekaspek pada suatu jabatan dalam suatu organisasi.

Berdasarkan pengamatan yang dilakukan peneliti, uraian tugas yang dilaksanakan di lapangan masih ada yang belum terdapat di uraian tugas tertulis dan ada juga yang tidak dilaksanakan dalam prakteknya. Berikut adalah tugas yang belum terdapat di uraian tugas tertulis dan yang belum dilaksanakan:

a. Melaksanakan pembuatan SEP untuk pasien BPJS rawat inap maupun rawat jalan

b. Melengkapi data sosial pasien pada status rawat inap

c. Melakukan pemesanan kamar melalui telefon dengan perawat bangsal

d. Menyediakan status rawat inap pasien

e. Memasukkan backup data pasien baru

f. Melakukan analisis kuantitatif

g. Melakukan klaim BPJS

h. Membuat Surat Keterangan Medis

3. Hambatan dan Solusi

Menurut Menkes RI (2007), salah satu kompetensi perekam medis adalah manajemen unit kerjamanajemen informasi kesehatan/rekam medis yaitu perekam medis mampu mengelola unit kerja yang berhubungan dengan perencanaan, pengorganisasian, penataan dan pengontrolan unit kerja manajemen informasi kesehatan (MIK)/rekam medis (RM) di instalasi pelayanan kesehatan.

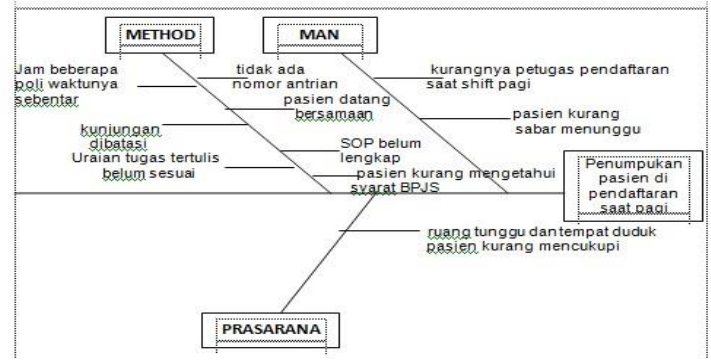

Gambar 1. Diagram Fishbone

Solusi untuk mengatasi penumpukan pasien dapat dilakukan dengan cara penambahan petugas pendaftaran di pagi hari atau dengan cara melakukan perbaikan sistem yang ada. Apabila penambahan jumlah petugas 
pendaftaran tidak memungkinkan maka solusi yang harus diambil adalah perbaikan sistem yang ada di poliklinik dan tempat pendaftaran pasien

4. Standar waktu kegiatan

Menurut Depkes RI (2004), kegiatan standar adalah satu satuan waktu (atau angka) yang diperlukan untuk menyelesaikan kegiatan pelayanan kesehatan oleh tenaga kesehatan sesuai dengan standar profesinya. Berdasarkan hasil observasi dan hasil perhitungan standar waktu pelayanan, waktu penyediaan dokumen rawat jalan adalah kurang dari 10 menit dan dokumen rawat inap pasien kurang dari 15 menit. Hal ini berarti standar pelayanan minimal penyediaan dokumen rawat jalan dan rawat inap di RS Aisyiah Muntilan telah sesuai dengan ketentuan yang ada. Berdasarkan hasil observasi waktu penyelesaian untuk pengolahan data dan pelaporan di Rumah Sakit Aisyiah Muntilan telah sesuai berdasarkan waktu yang telah ditentukan.

5. Menghitung kebutuhan petugas

$$
\text { Menurut hasibuan (2005), }
$$
perencanaan sumber daya manusia adalah merencanakan tenaga kerja agar sesuai dengan kebutuhan perusahaan serta efektif dan efisien dalam menbantu mewujudkan tujuan yang akan dicapai.

Menurut Depkes RI (2004), salah satu metode perencanaan tenaga adalah Workload Indicator Staffing Need (WISN), yaitu metode perhitungan kebutuhan SDM berdasarkan pada beban pekerjaan yang dilaksanakan oleh setiap petugas pada setiap unit kerja di fasilitas pelayanan kesehatan. kelebihan metode ini mudah dioperasikan, mudah digunakan, secara teknis mudah diterapkan, komprehensif, dan realistis.
Berikut adalah hasil perhitungan kebutuhan petugas di pendaftaran:

a. Pendaftaran pasien poliklinik dan fisiotherapi 1,77 petugas.

b. Pendaftaran pasien IGD, rawat inap dan laboratorium 0,4 petugas.

c. Pendaftaran pasien radiologi 0,07 petugas.

d. Pengolahan data dan pelaporan 2,1 petugas.

Hasil perhitungan secara keseluruhan, kebutuhan petugas pendaftaran adalah 2,24 petugas dan petugas pengolahan data dan pelaporan adalah 2,1 petugas sehingga tidak membutuhkan penambahan petugas. Namun, hasil perhitungan untuk kebutuhan petugas pendaftaran saat shift pagi adalah 1,77 petugas. Hal tersebut berarti kebutuhan petugas melebihi jumlah petugas pendaftaran yang ada yaitu 1 orang petugas. Namun, hal tersebut dapat diatasi dengan bantuan petugas pengolahan data dan pelaporan dengan tidak melebihi beban kerja yang harus ditanggung. Selain itu, penumpukan pasien yang terjadi saat shift pagi disebabkan karena kurang tepatnya sistem yang digunakan. Sistem pendaftaran pasien di Rumah Sakit Aisyiah Muntilan tidak menggunakan nomor antrian sehingga menyebabkan kurang tertibnya pasien saat mendaftar di tempat pendaftaran pasien, selanjutnya pelayanan di enam poliklinik memiliki waktu pelayanan yang terbatas sehingga menyebabkan terjadinya antrian pasien.

\section{PENUTUP}

A. KESIMPULAN

1. Jumlah petugas rekam medis di RS Aisyiah Muntilan adalah 7 orang petugas dengan rincian: 4 orang petugas pendaftaran dan 3 orang petugas pengolahan data dan pelaporan. 
2. Uraian tugas petugas rekam medis di RS Aisyiah Muntilan masih belum sesuai dengan uraian tugas tertulis yang ada.

3. Dalam proses pelaksanaannya terdapat beberapa hambatan yang dihadapi oleh petugas pendaftaran pasien, diantaranya: kurangnya petugas pendaftaran saat shift pagi, tidak adanya nomor antrian, ruang tunggu dan tempat duduk pasien yang kurang mencukupi, dibatasinya kunjungan dan waktu praktek beberapa poliklinik. Solusi yang diperlukan berdasarkan hambatan yang ada, diantaranya: penambahan jumlah petugas pendaftaran untuk shift pagi, membuat sistem nomor antrian, memperluas ruang tunggu dan menambah tempat duduk pasien di pendaftaran dan perbaikan penjadwalan poliklinik.

4. Standar waktu kegiatan di instalasi rekam medis untuk penyediaan dokumen rawat jalan dan rawat inap sudah sesuai dengan standar pelayanan minimal rumah sakit dan untuk pelaksanaan pengolahan data dan pelaporan telah dilaksanakan sesuai dengan batas waktu yang telah ditetapkan.

5. Berdasarkan hasil perhitungan kebutuhan petugas rekam medis dengan metode WISN diperoleh hasil:

a. Kebutuhan petugas pendaftaran 2,4 petugas

b. Kebutuhan petugas pengolahan data dan pelaporan 2,1 petugas.

Sehingga tidak dibutuhkan penambahan petugas namun perlu dilakukan perbaikan sistem yang ada di poliklinik dan tempat pendaftaran pasien.

\section{B. SARAN}

1. Sebaiknya dilakukan perbaikan terhadap uraian tugas tertulis sesuai dengan pelaksanaan di Instalasi Rekam Medis.

2. Sebaiknya di lakukan perbaikan SOP yang masih belum sesuai dan pembuatan SOP yang belum ada di Instalasi Rekam Medis.

3. Sebaiknya dilakukan sosialisasi kepada petugas rekam medis tentang uraian tugas dan prosedur pelayanan yang ada.

4. Sebaiknya dilakukan perbaikan penjadwalan poliklinik.

5. Sebaiknya dilakukan perbaikan prasarana ruang tunggu dan tempat duduk pasien di pendaftaran.

6. Sebaiknya dilakukan pemasangan pamphlet atau banner tentang syarat pasien BPJS.

7. Sebaiknya klaim BPJS dilakukan oleh petugas khusus BPJS.

\section{DAFTAR PUSTAKA}

Departemen Kesehatan RI. (2004). Peraturan Menteri Kesehatan Republik Indonesia Nomor 81/MENKES/SK/I/2004 tentang Pedoman Penyusunan Perencanaan SDM Kesehatan di Tingkat Propinsi, Kabupaten/Kota serta Rumah Sakit. www.depkes.go.id. Diakses pada tanggal 20 Desember 2015.

Menpan RI. (2013). Peraturan Menteri Pendayagunaan Aparatur Negara dan Reformasi birokrasi Nomor 30 tentang jabatan fungsional perekam medis dan angka Kreditnya. wWw.menpan.go.id. Diakses pada tanggal 5 Juni 2016.

Menkes RI. (2007). Peraturan Menteri Kesehatan Republik Indonesia Nomor 377/MENKES/SK/III/2007 tentang Standar Profesi Perekam Medis dan Informasi

Kesehatan. www.depkes.go.id. Diakses pada tanggal 12 Juni 2015. 